\title{
The magnitude of antibiotic resistance to Helicobacter pylori in Africa and identified mutations which confer resistance to antibiotics: systematic review and meta- analysis
}

Hyasinta Jaka ${ }^{*}$, Jee Ah. Rhee ${ }^{2}$, Linda Östlundh ${ }^{3}$, Luke Smart ${ }^{4}$, Robert Peck ${ }^{1,5}$, Andreas Mueller $^{6}$, Christa Kasang ${ }^{6}$ and Stephen E. Mshana ${ }^{7}$

\begin{abstract}
Background: Worldwide Helicobacter pylori (H.pylori) treatment is of great challenge due to increased antibiotic resistance. The burden of $\mathrm{H}$. pylori antibiotic resistance in Africa is high with unclear information regarding the real magnitude. This systematic review and meta-analysis was conducted to investigate the magnitude of H.pylori antibiotic resistance in Africa to gain insight of the extent of the problem among H.pylori naive treatment patients.

Method: The search was performed in the academic databases, Embase, PubMed, Web of Science and Africa Wide Information. ProQuest Dissertation and Theses, Scopus, Ethos, Africa Index Medicus (WHO), BioMed Central Proceedings, BASE, British Library, Open grey, Library of Congress and the New York Academy of Grey Literature Report were additionally searched for grey literature. Published articles from Africa on H.pylori antibiotic resistance between 1986 and June 2017 were systematically reviewed to estimate the H. pylori extent of resistance to macrolides, quinolones, amoxicillin, tetracycline and metronidazole.

Results: In 26 articles a total of 2085 isolates were tested for metronidazole, 1530 for amoxicillin, 1277 for tetracycline, 1752 for clarithromycin and 823 for quinolones.The overall pooled proportion of H.pylori resistance to quinolones, clarithromycin, tetracycline, metronidazole and amoxicillin were: $(17.4 \%, 95 \% \mathrm{Cl} 12.8-21.9),(29.2 \%, 95 \% \mathrm{Cl}: 26.7-31.8)$, (48.7\%, 95\%Cl: 44.5-52.9), (75.8\%, 95\% Cl: 74.1-.77.4) and (72.6\%, 95\% Cl: 68.6-76.6), respectively. The commonest mutation detected were A2143G (49/97) for clarithromycin, RdxA (41/56) for metronidazole and D87l (16/40) for quinolones.
\end{abstract}

Conclusion: Prevalence of metronidazole, clarithromycin, and amoxicillin resistance is high in developing world including Africa. This could impair the first line triple therapy of the H.pylori infection. There is a need of conducting surveillance of H.pylori susceptibility pattern in Africa for dual and triple resistance which can be used for the empirical treatment.

Keywords: H.Pylori, Drug resistance, Antibiotics resistance, Clarithromycin, Metronidazole, Quinolones, Africa

\footnotetext{
* Correspondence: yasintaliwa5@gmail.com

${ }^{1}$ Gastroenterology and Hepatology Unit, Weill Bugando School of Medicine,

Catholic University of Heath and Allied Sciences and Bugando Hospital

Mwanza, P.O. BOX 1464, Mwanza, Tanzania

Full list of author information is available at the end of the article
}

(c) The Author(s). 2018 Open Access This article is distributed under the terms of the Creative Commons Attribution 4.0 International License (http://creativecommons.org/licenses/by/4.0/), which permits unrestricted use, distribution, and reproduction in any medium, provided you give appropriate credit to the original author(s) and the source, provide a link to the Creative Commons license, and indicate if changes were made. The Creative Commons Public Domain Dedication waiver (http://creativecommons.org/publicdomain/zero/1.0/) applies to the data made available in this article, unless otherwise stated. 


\section{Background}

The prevalence of H.pylori infection varies worldwide among different geographical regions and correlates with diverse socio-demographic factors [1]. The H.pylori sero-positivity rate is much higher in developing countries than in industrialized countries [2]. The $H$. pylori sero-prevalence in East Africa has been found to range from $54.8 \%$ to $75 \%$, with prevalence of $45.7 \%$ to $65 \%$ reported in Tanzania [3-7]. H. pylori antibiotic resistance is increasing worldwide and is associated with low eradication rate [8]. The prevalence of $H$.pylori drug resistance varies from place to place, and is largely depends on the quantity of antibiotics used in that particular population $[9,10]$. Overall H.pylori antibiotic resistance is of increase in America, Asia and Africa $[8,10]$.

In developing countries including Tanzania, the first line treatment option against H.pylori includes; clarithromycin, metronidazole/ tinidazole, amoxicillin and tetracycline while the second line option includes; levofloxacin, rifabutin and furazolidon. According to the guidelines, the first regimen are the triple-therapy, quadruple therapy and quinolone containing regimen. Triple-therapy treatment regimens consist of proton pump inhibitor and two antibiotics: amoxicillin and clarithromycin, or metronidazole and clarithromycin while quadruple therapy consist of proton pump inhibitor, bismuth and two antibiotics: amoxicillin plus clarithromycin, or metronidazole plus tetracycline. There is Non bismuth quadruple therapy (concomitant) which includes proton pump inhibitor, amoxicillin, metronidazole, clarithromycin or (sequential) five days proton pump inhibitor and amoxicillin followed by seven days proton pump inhibitor, metronidazole and clarithromycin. The second line (salvage therapy) treatment includes quinolone containing regimen which consist of proton pump inhibitor, amoxicillin and levofloxacin and Rifabutin, amoxicillin and proton pump inhibitor [11-14].

The rates of resistance to metronidazole and clarithromycin are increasing worldwide $[15,16]$. The metronidazole resistance rate increased from $26.7 \%$ in 2010 to $47.2 \%$ in 2015, while tetracycline resistance increased from 5.9\% in 2010 to $11.7 \%$ in 2015 [8, 15]. In addition, the resistance to clarithromycin has been found to increase from $17.2 \%$ in 2010 to more than $19.7 \%$ in 2017 [8, 15, 17]. In Africa, H.pylori treatment is much compromised by antibiotic resistance in about $58 \%-95 \%$ of patients who are treated by the triple therapy $[6,18]$. Data on the overall H.pylori drug resistance in Africa has never been compiled to show the magnitude of the problem. Therefore, this systematic review and meta-analysis aimed at quantifying the magnitude of H.pylori drug resistance in Africa among H. pylori naïve treatment patients.

\section{Methods}

\section{Eligibility criteria}

The review included; full articles which investigated on H.pylori resistance in any African country among naïve to $H$. pylori treatment patients.

\section{Information sources}

A comprehensive systematic search for literature was conducted in major medical and health science databases, and sources of grey literature. The search was performed in the academic databases, PubMed, Embase, Web of Science and Africa Wide Information. ProQuest Dissertation and Theses, Ethos, Scopus, Africa Index Medicus (WHO), Open Grey, BASE, BioMed Central Proceedings, British Library, Library of Congress and the New York Academy of Grey Literature Report were additionally searched for grey literature.

\section{Search strategy}

Pre-search was conducted between November 2015 and May 2016 to identify relevant keywords and information sources for best possible retrieval of information about $H$. pylori drug resistance in Africa (Additional file 1). A search strategy was initially developed in PubMed and later applied in all selected databases. PubMed's MeSH was used for systematic inclusion and exclusion of all search terms. This was specifically helpful in identifying all African countries. A list of all previous country names, in addition to current names, compiled based on $\mathrm{MeSH}$ "Entry Terms" for each country, and reviewed to only included names from 1986 (Additional file 2).

All keywords included were searched with a combination of the fields "Title", "Abstract" (alternatively "Topic") and "Thesaurus"/"Subject Headings", when available, to maximize the search outcome. No filters or limitations were applied to ensure inclusion of pre-indexed materials. A full search log, including notes and results for all search sessions, can be found in Additional file 2 .

\section{Study selection}

The systematic review software Covidence was used and manual screening was also conducted of all references in the grey literature. Thus, after duplicate removal, a total of 389 abstracts were identified, among these, 352 were excluded due to the following reasons; not about H.pylori (213), not about H.pylori resistance (86), review and report (25), not Africa (20), conference (2), animal study (1), duplicate (4), guidelines (1). The articles from grey search were 62 , among these 56 were excluded and 6 articles were included in the full test assessment. Full-text articles were assessed for eligibility (37 from data base and 6 from grey literature). Out of 43 articles, 17 (12 from data base and 5 from grey literature) were excluded because they 
had missing information /data, therefore only 26 articles were included in the final analysis (Fig. 1).

\section{Data collection process and assessment of methodological quality}

Relevant articles were independently reviewed by two authors. Data were extracted from each article into an excel spread sheet, which included name of authors, year of publication, country, study population, sample size, samples of isolates, antibiotic tested for resistance, susceptibility results and criteria used and possible mutations detected.

Studies were objectively assessed using the previously validated Newcastle-Ottawa score, which scores of a 6point scale according to performance in first two categories of sample selection criteria(4) and comparability on the bases of design or analysis(2) while the outcome was not assessed (this is for case control and cohort studies).

\section{Summary measures}

STATA version 13 (College Station, Texas 77,845 USA) was used to perform meta-analysis of the proportion of $\mathrm{H}$. pylori resistance rates to clarithromycin, metronidazole, amoxicillin and quinolones. In the analysis, a random- effects model was used to calculate the pooled (weighted) resistance rates for each antibiotic. Moreover, for percentages, the 95\% confidence intervals were calculated. Heterogeneity was assessed by Cochran's $\mathrm{Q}$ test $\left(\mathrm{I}^{2}\right)$.

\section{Results}

\section{Study selection}

A total of 732 references were finally located through the search in academic databases and reduced to 389 after duplicate removal. In order to find grey materials, the search string was broaden and adapted to available search tools in the different sources. The grey search resulted in 78 references with a final number of 62 after de- duplication.

A total of 26 studies from different parts of Africa published between 1986 and 2017 were found and reviewed. There were six studies from Nigeria, three from South Africa and Egypt; Kenya, Senegal and Ethiopia had two studies each, while Tunisia, Malawi, Congo Brazzaville, Gambia, Uganda, Morocco, Algeria and Cameroon had one study each (Table 1). There were 4324 patients involved in the study. Most of the patients aged between $1 \frac{1 / 2}{2}$ and 90 yrs. These studies involved

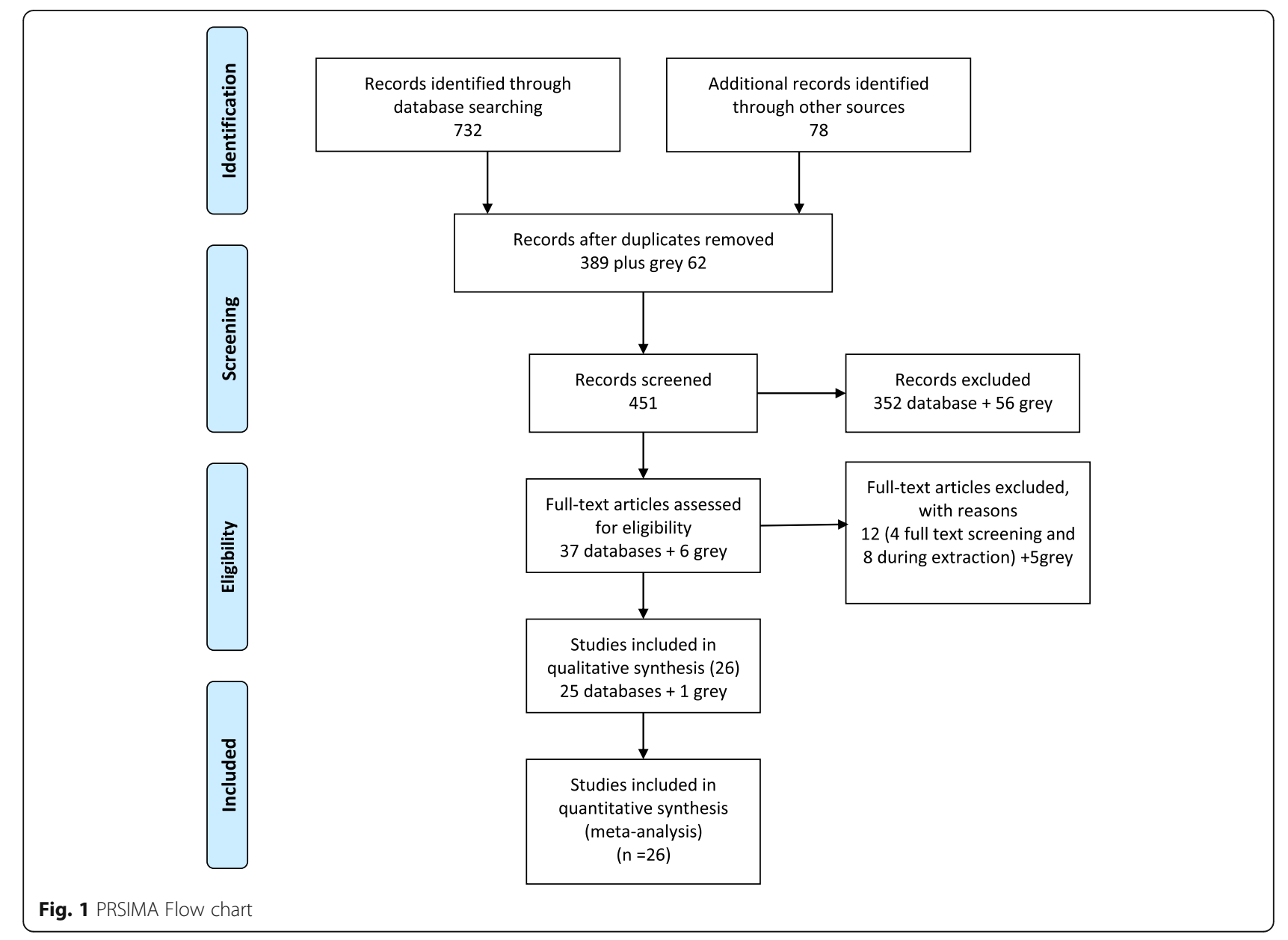


Table 1 Baseline characteristics of 26 studies in Africa from 1992 to 2017

\begin{tabular}{|c|c|c|c|c|c|c|c|}
\hline Author & Country & $\begin{array}{l}\text { Publication } \\
\text { year }\end{array}$ & Sample size & Age Mean \pm SD & Age Range & Drugs & Ref \\
\hline Abdurashhed Abdul & Nigeria & 2005 & 25 & $49.3 \pm 16.8$ & $20-73$ & Amo,Cip,Cla,clind,Eryth,Met,tet & {$[20]$} \\
\hline Aboderin Oladiipo & Nigeria & 2007 & 32 & $48.6 \pm 16.23$ & $20-73$ & Amo,Tet,Cip, Cla,Eryth,Met,_Rifamp & [21] \\
\hline Adeniyi A.Bolande & Nigeria & 2012 & 52 & - & $10-90$ & $\begin{array}{l}\text { Aug,Amo,Tet,Eryth,Clox,Genta,Cotr, } \\
\text { Chlor,Nitro,Nalid,Oflox,Cla,met,Cefs, } \\
\text { Ceph,Vanc,Tob,Kana,Clind }\end{array}$ & [63] \\
\hline Angol C Denish & Uganda & 2017 & 142 & $40 \pm 18$ & $13-85$ & Cla,quino & [64] \\
\hline Ani Agatha.E & Nigeria & 1999 & 87 & - & - & Amo,Cla,Met,Tet & [26] \\
\hline Asrat Daniel & Ethiopia & 2004 & 50 & - & - & Cla,Eryth,Tet,Met,Amo & [24] \\
\hline Bouihat Najat & Morocco & 2016 & 255 & & & Met, Cla, levo, Rifam, Amox, Tet & [33] \\
\hline Fathi Marwa S & Egypt & 2013 & 60 & $46.7 \pm 8.8$ & $50-60$ & Cla,Cip,Tet,Met,Amo & [22] \\
\hline Ghaith Doaa & Egypt & 2016 & 100 & $44 \pm 11$ & $21-60$ & $\mathrm{Cla}$ & [65] \\
\hline Hadibi D.Fazia & Algeria & 2016 & 195 & & & $\mathrm{Cla}$ & [66] \\
\hline Harries A.D & Malawi & 1992 & 136 & - & $18-70$ & Met,Pen,Tet,Amo & [29] \\
\hline Harrison Ute & Nigeria & 2017 & 577 & & & Met,Amox,Cla,Tet & [67] \\
\hline $\begin{array}{l}\text { Kimanga Andrew } \\
\text { Nyerere }\end{array}$ & Kenya & 2010 & 70 & - & - & Amo,Met,Cla & [4] \\
\hline Lwai-lume L & Kenya & 2005 & 267 & $45.4 \pm 17.6$ & $15-85$ & Cla,Amo,Tet,Met & [68] \\
\hline Mansour Khansa Ben & Tunisia & 2010 & 273 & 38.3 & - & Amo,Met,Cla & [27] \\
\hline Nicoline F. Tanih & South Africa & 2010 & 200 & - & - & Amo,Cip,Cla,Gent,Eryth,Met,Tet & [31] \\
\hline Nicoline F. Tanih & South Africa & 2011 & 254 & $45.5+15.7$ & $5-93$ & Met,Cla & [55] \\
\hline Nicoline F. Tanih & South Africa & 2013 & 254 & - & - & Cla, Quin & [34] \\
\hline Ngoyi, Ontsira Nina E & Congo Brazavil & 2015 & 63 & $43.9 \pm 15.3$ & $17-76$ & Cla,Tet,Quin, & [32] \\
\hline Ndip N.Roland & Cameroon & 2008 & 77 & $44.5 \pm 15.7$ & $15-77$ & Met,Tet,AMo,Cla & [69] \\
\hline Seck Abdoulaye & Senegal & 2009 & 40 & - & - & Met, Cip,Amo & [28] \\
\hline Seck Abdoulaye & Senegal & 2013 & 108 & 45.3 & 18-93 & Amo, Tet,Met, Cla, Lev & [30] \\
\hline SeckaOusman & Gambia & 2013 & 169 & 30 & $11 / 2-70$ & Met,Cla,Tet,Amo & [25] \\
\hline Thor-H. Henriksen & Ethiopia & 1999 & 290 & - & - & Amo,Dox,Met & [18] \\
\hline Sherif May & Egypt & 2004 & 48 & - & $2-17$ & Amp,Cla,Eryth,Azyth,Met,Cip & [23] \\
\hline Smith I. Stella & Nigeria & 2001 & 532 & - & - & $\begin{array}{l}\text { Cip,Met,Amox,Pip,Ery,Imep,Gent, } \\
\text { kan,ofl,Nor,Cef }\end{array}$ & [70] \\
\hline Total & & & 4324 & & $11 / 2-93$ & & \\
\hline
\end{tabular}

Amo: Amoxicillin; Amp:Ampicillin; Aug: Augumentine:;Azyth: Azythromycin; Cip: Ciprofloxacin; Cla: Clarithromycin; Clin: Clindamycin; Clox: Cloxacicilin; Cotri:Cotrimoxazol; Dox; Doxycycline; Cef:ceftriaxone; Ceph: Cephalexin; Eryth: Erythromycin; Gent:Gentamycin; Kan:Kanamycin; Met: Metronidazole; Nal:Nalidixic acid; Oflo:Ofloxacin; Tet: Tetracycline; Lev: Levofloxacin;Rifamp: RifampicinRifam: Rifamycin; Fur: Furazolidon; Quin:Quinolones; Van:Vancomycin

between 1 to 25 antibiotics among which some are not used in the H.pylori treatment regimens. The statistical heterogeneity was quantified and reported for each antibiotic resistance by I square. Overall studies included in this review were heterogeneous and the I square remained significant even after removing the outliers.

\section{Description of the studies}

The review included 26 articles research articles, data in these articles were collected between 1986 and 2017. The majority of the studies were done in West Africa and East Africa. Out of 26 studies, 13(50\%) used both disc method and E-test method for susceptibility testing, while 10 studies used PCR and culture, and 4 studies used only PCR technique (Table 2). The presence or absence of mutations conferring resistance to various antibiotics was reported in 18 articles and only one study did follow up of the patients to assess treatment outcome.

\section{Susceptibility testing}

Despite high heterogeneity of the studies of more than $99 \%$, the pooled susceptibility results have been reported with clear documentation of the number of isolates tested. A total of 2430 isolates were tested for various antibiotics using different methods as detailed in Table 2 . Out of 2085 isolates tested for metronidazole, the 
Table 2 Methods of identification and susceptibility method used

\begin{tabular}{|c|c|c|c|c|c|c|}
\hline \multirow[t]{2}{*}{ AUTHOR } & \multirow[b]{2}{*}{ Isolate } & \multicolumn{2}{|c|}{ METHOD USED } & \multirow{2}{*}{$\begin{array}{l}\text { SUSCEPTIBILITY } \\
\text { METHOD }\end{array}$} & \multirow[t]{2}{*}{ INTERPRETATION CRITERIA } & \multirow[t]{2}{*}{ REF } \\
\hline & & CULTURE & $P C R$ & & & \\
\hline Abdurashhed et al & 20 & YES & NO & disc diffusion & NCCLS & [71] \\
\hline Aboderin et al. 2007 & 31 & YES & NO & disc diffusion & NCCLS & [71] \\
\hline Adeniyi et al. 2012 & 33 & YES & NO & disc diffusion & not documented & - \\
\hline Angol C Denish & 21 & NO & YES & - & - & {$[64]$} \\
\hline Ani et al. 1999 & 55 & YES & NO & E-test & $\begin{array}{l}\text { Thomsbbery, C. (1985);Hachem, } \\
\text { C. Y., (1996). }\end{array}$ & {$[72,73]$} \\
\hline Asrat et al. 2004 & 50 & YES & NO & E-test & Cederbrant G,1993 & [74] \\
\hline Bouihat Najat & 255 & YES & YES & $\begin{array}{l}\text { E-test } \\
\text { Disc diffusion }\end{array}$ & CLSI & {$[33]$} \\
\hline Fathi et al... 2013 & 16 & YES & YES & $\begin{array}{l}\text { E-test, } \\
\text { Disc diffusion }\end{array}$ & CLSI & {$[75]$} \\
\hline Ghaith et al. 2016 & 70 & NO & YES & - & - & {$[65]$} \\
\hline Hadibi et al. 2016 & 91 & NO & YES & - & - & {$[66]$} \\
\hline Harries et al. 1992 & 50 & YES & NO & disc diffusion & not documented & - \\
\hline Harrison et al. 2016 & 111 & YES & YES & E-Test & CLSI & {$[67]$} \\
\hline Kimanga et al. 2000 & 65 & YES & NO & E-test & CLSI & [75] \\
\hline Lwai-Lume et al. 2005 & 108 & YES & NO & E-test & NCCLS & - \\
\hline Mansour et al. 2010 & 273 & YES & YES & E-test & Chaabouni H, (2004) & {$[76]$} \\
\hline Nicoline et al. 2010 & 191 & YES & NO & disc diffusion & CLSI & {$[75]$} \\
\hline Nicoline et al. 2011 & 200 & YES & YES & disc diffusion & CLSI & {$[75]$} \\
\hline Nicoline et al. 2013 & 78 & YES & YES & disc diffusion & N. F. Tanih (2010) & {$[31]$} \\
\hline Ngoyi et al. 2015 & 56 & NO & YES & NA & NA & - \\
\hline Roland et al. 2008 & 132 & YES & YES & disc diffusion & NCCLS & [71] \\
\hline Seck et al. 2009 & 40 & YES & $\mathrm{NO}$ & E-test & Megraud F (1999) & [77] \\
\hline Seck et al. 2013 & 108 & YES & YES & E-test & CLSI & {$[75]$} \\
\hline Secka et al. 2013 & 64 & YES & YES & E-test & not documented & - \\
\hline Sherif et al. 2004 & 48 & YES & NO & E-test & not documented & - \\
\hline Smith et al. 2001 & 245 & YES & YES & $\begin{array}{l}\text { E-test, } \\
\text { Disc diffusion }\end{array}$ & NCCLS & [70] \\
\hline Thor-Henric et al. 1999 & 19 & YES & NO & disc diffusion & Cederbrant G,.1993 & [74] \\
\hline TOTAL & 2430 & & & & & \\
\hline
\end{tabular}

resistance was found to range from $4.6 \%$ in the study in Kenya [19] to 100\% in Egypt and Nigeria [20-23]; the overall resistance was 75.8\% (95\% CI: 74.1-.77.4) (Fig. 2). Regarding clarithromycin, the potent first line drug for $H$. pylori treatment the rate of resistance ranged from $0 \%$ in Gambia, Kenya and Ethiopia to 100\% in Egypt and Nigeria [19-22, 24, 25], with overall resistance of $29.2 \%$, (95\%CI:26.7-31.8) (Fig. 3). Among 1530 isolates tested for amoxicillin, $72.6 \%$ (95\% CI: 68.6-76.6) were found to be resistant (Fig. 4) [19-21, 26-28]. Of 1277 isolates tested for tetracycline, the overall resistance was $48.7 \%(95 \% \mathrm{CI}$ : 44.5-52.9) [20, 24, 25, 29, 30]. Regarding quinolones, a total of 823 H.pylori isolates were tested, the resistance ranged from $0 \%$ to $32 \%[20,28,31,32]$ with the overall resistance of $17.4 \%$ (95\%CI 12.8 - 21.9). The resistance to rifampicin was $87.1 \%$ and none of the isolates were resistant to rifamycin $[21,33]$.

\section{H.pylori mutations in Africa}

A total of 334 isolates were tested for various mutations conferring resistance to clarithromycin. The commonest mutation detected was A2143G which was observed in 49 isolates (Table 3). Out of 60 isolates tested for quinolone mutations, $40(66.7 \%)$ were found to have mutations conferring resistance to quinolones. The commonest mutations was D87I which occurred in 16 isolates, followed by D91N occurring in 14 isolates [30, 32, 34]. The rdxA (41/66) was the commonest mutation detected to confer resistance to metronidazole [22, 25, 31]. Mutations conferring resistance to tetracycline were investigated in 40 isolates, and only 


\begin{tabular}{|c|c|c|c|}
\hline \multicolumn{3}{|l|}{ Study } & \multirow{2}{*}{$\begin{array}{l}\% \\
\text { Weight }\end{array}$} \\
\hline ID & & ES $(95 \% \mathrm{Cl})$ & \\
\hline Adeniyi et al 2012 (Nigeria) & & $94.00(85.90,102.00)$ & 2.64 \\
\hline Ani et al 1999 (Nigeria) & $\rightarrow-$ & $40.00(27.00,53.00)$ & 1.87 \\
\hline Asrat et al 2004(Ethiopia) & & $76.00(64.00,88.00)$ & 3.24 \\
\hline Bouihat et al 2016(Morocco) & 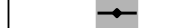 & $40.10(32.90,47.30)$ & 6.05 \\
\hline Harries et al 1992(Malawi) & $\rightarrow$ & $37.00(27.50,46.50)$ & 3.15 \\
\hline Harrison et al 2017(Nigeria) & & $99.10(97.30,100.80)$ & 9.37 \\
\hline Henriksen et al 1999(Ethiopia) & & $95.00(85.20,104.00)$ & 1.53 \\
\hline Kimanga et al 2000(Kenya) & $\rightarrow$ & $4.60(0.49,9.70)$ & 0.26 \\
\hline Lwai-Lume et al 2005 (Kenya) & & $81.00(74.50,87.80)$ & 9.20 \\
\hline Mansour et al 2010(Tunisia) & $\rightarrow$ & $51.30(45.30,57.20)$ & 11.93 \\
\hline Ndip et al 2008 (Cameroon) & $\rightarrow$ & $51.20(44.90,57.60)$ & 10.48 \\
\hline Nicoline et al 2011(South Africa) & & $95.50(92.60,98.40)$ & 16.27 \\
\hline Seck et al 2009(Senegal) & & $90.00(80.70,99.30)$ & 3.07 \\
\hline Seck et al 2013(Senegal) & & $85.00(81.80,94.10)$ & 7.84 \\
\hline Secka et al 2013(Gambia) & & $68.00(56.60,79.40)$ & 3.75 \\
\hline Smith et al 2001(Nigeria) & & $99.10(97.30,100.80)$ & 9.37 \\
\hline Abdurashhed et al 2005(Nigeria) & & (Excluded) & 1.70 \\
\hline Aboderin et al 2007(Nigeria) & & (Excluded) & 2.64 \\
\hline Fathi et al 2013 (Egypty) & & (Excluded) & 1.36 \\
\hline Nicoline et al 2010(South Africa) & & (Excluded) & 16.27 \\
\hline Sherif et al 2004(Egypty) & & (Excluded) & 4.09 \\
\hline Overall (I-squared $=99.5 \%, p=0.000$ ) & & $75.76(74.13,77.39)$ & 100.00 \\
\hline
\end{tabular}

Fig. 2 Proportional estimate of metronidazole with 95\% confidence interval. Midpoint of each horizontal line segments shows the proportional estimate of metronidazole resistance for each study while the rhombic mark shows the pooled proportions for all studies

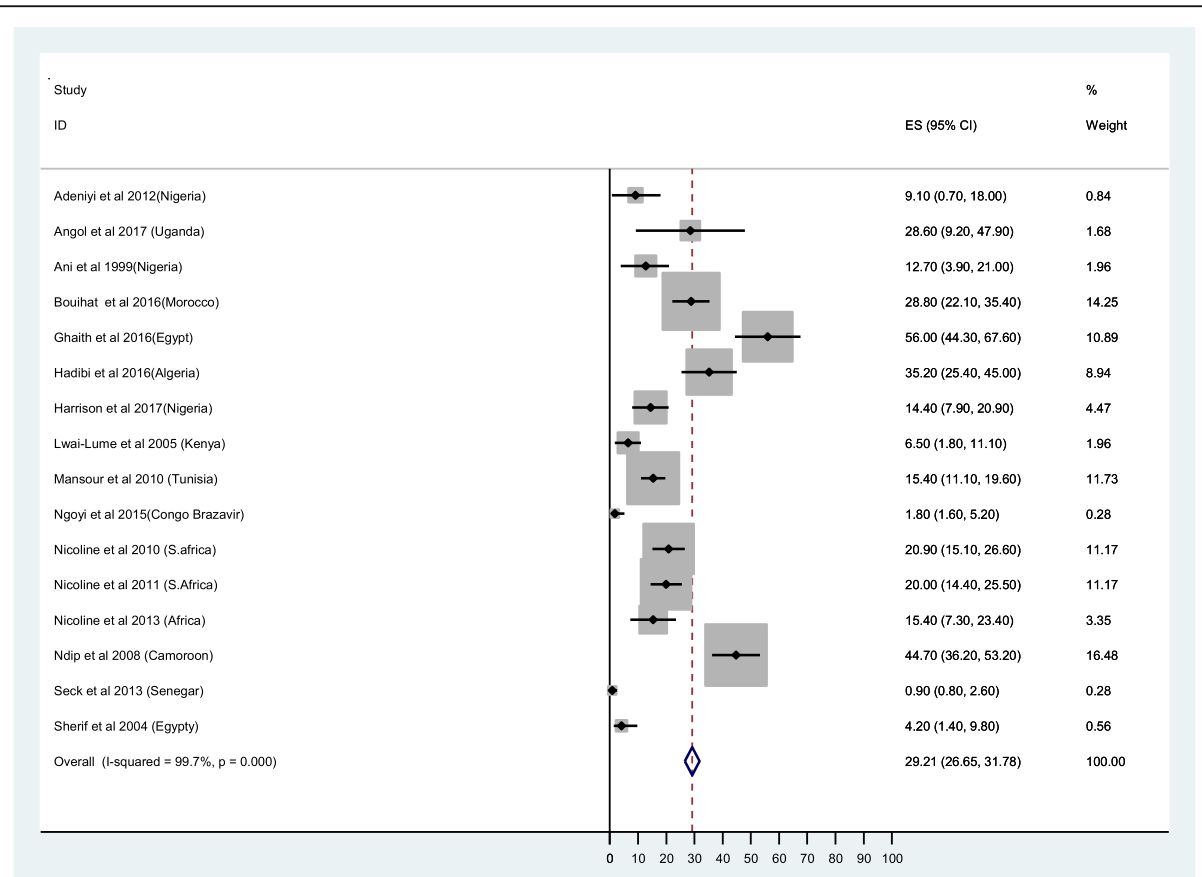

Fig. 3 Proportional estimate of clarithromycin with 95\% confidence interval. Midpoint of each horizontal line segments shows the proportional estimate of clarithromycin resistance for each study while the rhombic mark shows the pooled proportions for all studies 


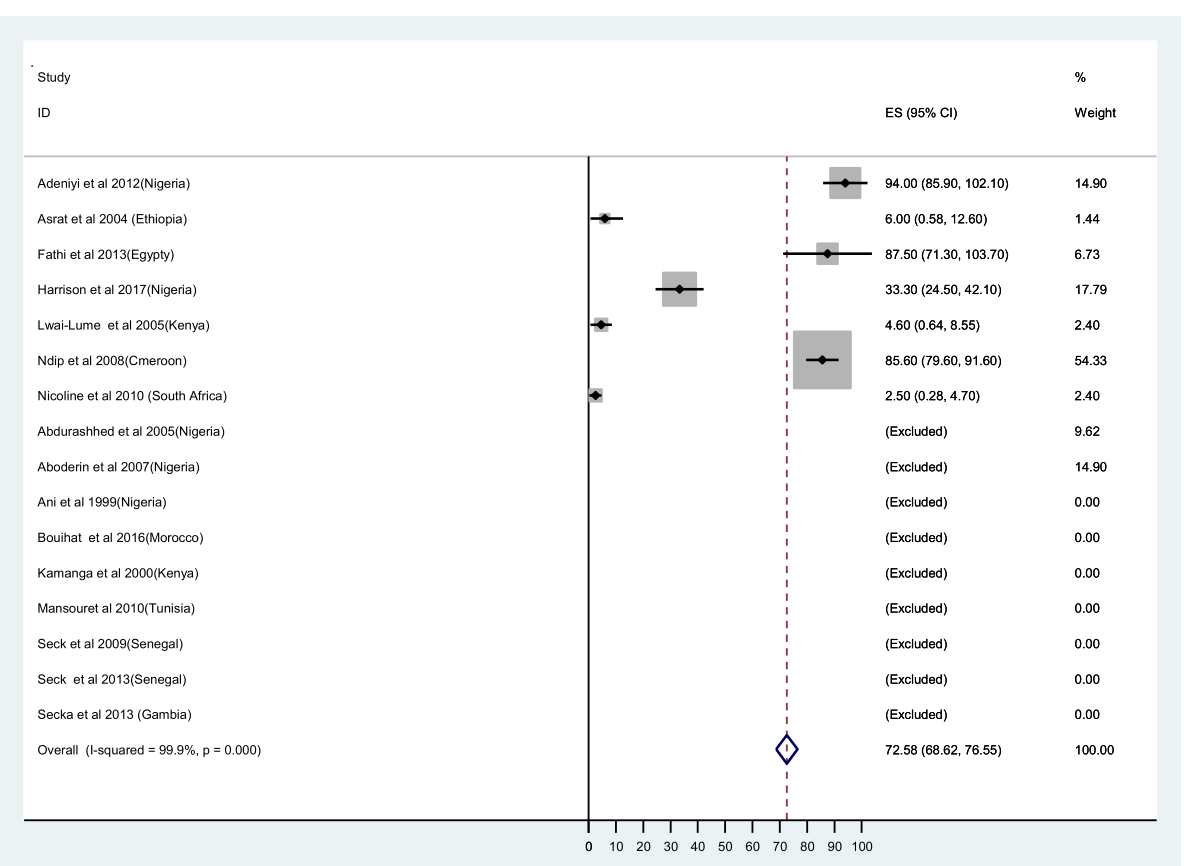

Fig. 4 Proportional estimate of amoxicillin with 95\% confidence interval. Midpoint of each horizontal line segments shows the proportional estimate of amoxicillin resistance for each study while the rhombic mark shows the pooled proportions for all studies

one isolate was found to carry AGC926-928 mutation [32] (Table 3).

\section{Discussion}

Treatment guidelines for the management of $H$. pylori infection in developing countries have recommended first, second and rescue therapy depending on the local

Table 3 Mutations distribution

\begin{tabular}{|c|c|c|c|c|}
\hline DRUGS & $\begin{array}{l}\text { Isolates tested } \\
\text { for mutations }\end{array}$ & $\begin{array}{l}\text { Total } \\
\text { mutation } \\
\text { detected }\end{array}$ & $\begin{array}{l}\text { Type of } \\
\text { Mutations }\end{array}$ & $\begin{array}{l}\text { Frequency } \\
\text { (\%) }\end{array}$ \\
\hline \multirow[t]{7}{*}{ CLARITHROMYCIN } & 334 & 97 & A2143G & $49(50.5 \%)$ \\
\hline & & & $A 2142 G$ & $24(25 \%)$ \\
\hline & & & A2147G & $17(17.5 \%)$ \\
\hline & & & A2146C & $1(1 \%)$ \\
\hline & & & A2142C & $2(2 \%)$ \\
\hline & & & $\mathrm{A} 2144 \mathrm{G}$ & $2(2 \%)$ \\
\hline & & & A2143C & $2(2 \%)$ \\
\hline \multirow[t]{5}{*}{ QUINOLONES } & 60 & 40 & D87| & $16(40 \%)$ \\
\hline & & & D91N & $14(35 \%)$ \\
\hline & & & D91G & $1(2.5 \%)$ \\
\hline & & & D91Y & $1(2.5 \%)$ \\
\hline & & & N87 K & $8(20 \%)$ \\
\hline \multirow[t]{2}{*}{ METRONIDAZOLE } & 66 & 56 & $\mathrm{RdxA}(41)$ & $41(73.2 \%)$ \\
\hline & & & FrxA (15) & $15(26.8 \%)$ \\
\hline TETRACYCLINE & 40 & 1 & AGA926-928 & 1 (100\%) \\
\hline
\end{tabular}

susceptibility pattern $[8,9]$ however, this is not routinely practiced due to the poor resources in these regions. As a result of increased resistance to $H$. pylori, the eradication rates of H.pylori have been found to be lower than $80 \%$ [9-11].

The worldwide prevalence of metronidazole resistance has been found to range from is $31 \%-53 \%$ in Europe and South America, and between $64 \%$ and $80 \%$ in Iran and Saudi Arabia [15, 35, 36]. In this review despite high heterogeneity of the studies the overall metronidazole resistance was $75.8 \%$ which is significantly higher than that observed in Europe and America. The use of metronidazole in the treatment of other endemic diseases such as diarrheal and protozoa diseases, could explain the significantly high rate of metronidazole resistance in Africa. It should be noted that the regimen used to treat other conditions provide sub-optimal concentration that cannot eradicate $H$. pylori strains hence selection of resistant H.pylori strains [37, 38].

In contrast to the observed high metronidazole resistance, the overall clarithromycin resistance in Africa was almost the same as that observed in North America $(30.8 \%)$ and in Portuguese (42.3\%). However, the observed resistance was significantly higher than that observed in middle Eastern countries (0-8\%) [10,36] and that documented in some parts of Europe and South America [15]. The use macrolides in outpatients setting has been associated with clarithromycin resistance [39]. In Africa, the resistance to clarithromycin could be 
linked to the high use of macrolides in the treatment of communicable diseases which are very prevalent, further studies to confirm this are warranted.

Regarding amoxicillin, the observed overall resistance was $72.6 \%$, which is significantly higher than that observed in Europe (0.35\%), North America (2\%), South America (6.6\%) and Asia (23.6\%). Similar trend of the amoxicillin resistance has been observed in other pathogens [40]. In Africa amoxicillin/ampicillin is the most abused antibiotics both in rural and in urban areas [41] because it is cheaply available in oral formulation. Additionally, in Africa the observed tetracycline resistance (49.8\%) was comparable to that in Asia which was found to range from $0.01 \%$ in Japan to $53.8 \%$ in India [15]. This high resistance to tetracycline could lead to the failure of novel three-in-one capsule of bismuth quadruple therapy that has proven effective as the first line of treatment in areas of high clarithromycin or metronidazole resistance [13]. It should be noted that this high resistance to tetracycline in Africa could be explained by the fact that tetracycline is readily misused in the treatment of pneumonia, acne and sexually transmitted infections [42] hence selecting for H.pylori resistant strains.

The rate of quinolone resistance observed in Africa is almost similar to that documented in South America (21\%), Asia(25.3\%) and North America (19\%) but higher than that in Europe (14.2\%) [15].

Rifabutin-based triple therapy has been found to be a useful salvage therapy in treatment of H.pylori. Rifabutin is derived from rifampicin and is used in rescue treatment of tuberculosis, this has also antimicrobial activity against H. pylori. In Africa there is no studies which were done on rifabutin instead two studies reported on rifamycin $87 \%$ in 2009 and rifampicin 0\% in 2016 which shows the resistance is declining in this drug group. This might be due to the careful use of anti-Tuberculosis drugs.

\section{Mutations}

$H$, pylori strains in Africa were found to carry A2143G, A2142G, A2147G and A2146C mutations that can lead to clarithromycin-resistance. Similar mutations have been observed in Asia [43, 44] and in South America, Europe and North America [45-49]. This can be due to migration process of human being [50]. In other part of the World in addition to these mutations other mutations in different positions have been found to confer clarithromycin resistance in $H$ pylori strains (T2182C, T2190C, C2195T, A2223G, G2141A, C2694A, G2224A, C2245T, T2289C) [51-53]. The addition mutations in other part of the World can be due to phylogeographic tree differences of H. pylori by either gain(recombination) or gene loss(loss by deletion) in multiple strains which result in sequence and gene content diversity [54]. Metronidazole mutations $[22,25,55]$ and quinolones mutations [56-58] observed in Africa were similar to that observed in Europe, in Asia and America.

In our review H.pylori mutation conferring resistance to tetracycline had two base pair mutation AGC926928 as observed in Congo Brazzaville, similar mutation was obtained in other parts of the world, in America $[59,60]$, Europe and Asia [61, 62].

One of the major limitation of this review is significantly high heterogeneity of the studies, this could be due to lack of methods standardization, heterogeneity of the population, and difference in discs quality. Despite this limitation the magnitude the data have been presented to highlight the importance of the problem and the need for standardized surveillance system.

\section{Conclusion}

Significantly high proportion of $H$. pylori strains in Africa are resistant to metronidazole, clarithromycin and amoxicillin. There is a need of conducting standardized surveillance of H.pylori susceptibility pattern in Africa to provide data that can be used to establish effective empirical treatment.

\section{Additional files}

Additional file 1: African countries included in the systematic search based on PubMed's. (DOCX 25 kb)

Additional file 2: Academic Databases. (DOCX $26 \mathrm{~kb}$ )

\section{Abbreviations}

CLSI: The Clinical Laboratory Standards Institute; E-Test: Epsilometer test; FrxA: gene which encodes for NAD (P) H Flavin oxidoreductase; NA: Not applicable; NCCLS: National Committee for Clinical Laboratory Standards (currently is known as Clinical laboratory Standard Institute (CLSI); PCR: Polymerase chain reaction; RdxA: gene, which encodes an oxygeninsensitive NADPH Nitroreductase

\section{Acknowledgements \\ The authors acknowledge the technical support from Catholic University of health and Allied Sciences and Zonal Health Resources Centre-Lake zone Tanzania. \\ Authors' contributions \\ HJ: made substantial contributions to conception and design acquisition of data, data analysis, interpretation and drafting the first of the manuscript, JR \&LO: made substantial contributions in acquisition of data and were involved in drafting the manuscript, LS, RP, AM \& CK: made substantial contributions in conception and design and critically revised the manuscript, SEM: made substantial contributions in conception and design, analysis and interpretation of data and critically revised the manuscript. All authors approved the final manuscript version to be published and agreed to be accountable for all aspects of the work.}

Ethics approval and consent to participate Not applicable

Competing interests

The authors declare that they have no competing interests. 


\section{Publisher's Note}

Springer Nature remains neutral with regard to jurisdictional claims in published maps and institutional affiliations.

\begin{abstract}
Author details
'Gastroenterology and Hepatology Unit, Weill Bugando School of Medicine, Catholic University of Heath and Allied Sciences and Bugando Hospital Mwanza, P.O. BOX 1464, Mwanza, Tanzania. ${ }^{2}$ Weill Cornell Medicine-Qatar, Doha, Qatar. ${ }^{3}$ National Medical Library, United Arab Emirates University, Abu Dhabi, United Arab Emirates. ${ }^{4}$ Cincinnati Children's Hospital Medical Centre, Cincinnati, Ohio, USA. ${ }^{5}$ Center for Global Health, Weill Cornell Medicine, New York, NY, USA. ${ }^{6}$ Medical Mission Institute Wuerzburg, Wuerzburg, Germany. ${ }^{7}$ Department of Microbiology and Immunology, Weill Bugando School of Medicine, Catholic University of Heath and Allied Sciences Mwanza, Mwanza, Tanzania.
\end{abstract}

\section{Received: 18 December 2017 Accepted: 17 April 2018}

\section{Published online: 24 April 2018}

\section{References}

1. Tanih N, Dube C, Green E, Mkwetshana N, Clarke A, Ndip L, Ndip R. An African perspective on Helicobacter pylori: prevalence of human infection, drug resistance, and alternative approaches to treatment. Ann Trop Med Parasitol. 2009:103(3):189-204.

2. Hellmig S, Hampe J, Schreiber S: Helicobacter pylori infection in Africa and Europe: enigma of host genetics. Gut 2003, 52(12):1799-1799.

3. Ayana SM, Swai B, Maro V, Kibiki GS. Upper gastrointestinal endoscopic findings and prevalence of Helicobacter pylori infection among adult patients with dyspepsia in northern Tanzania. Tanzan J Health Res. 2014;16(1)

4. Kimang'a AN, Revathi G, Kariuki S, Sayed S, Devani S. Helicobacter pylori: prevalence and antibiotic susceptibility among Kenyans. S Afr Med J. 2010; 100(1):53-7.

5. Mathewos B, Moges B, Dagnew M. Seroprevalence and trend of Helicobacter pylori infection in Gondar University hospital among dyspeptic patients, Gondar, north West Ethiopia. BMC Res Notes. 2013;6(1):346.

6. Walker TD, Karemera M, Ngabonziza F, Kyamanywa P. Helicobacter pylori status and associated gastroscopic diagnoses in a tertiary hospital endoscopy population in Rwanda. Trans R Soc Trop Med Hyg. 2014; 108(5):305-7.

7. Jaka H, Mushi MF, Mirambo MM, Wilson L, Seni J, Mtebe M, Mshana SE. Sero-prevalence and associated factors of Helicobacter pylori infection among adult patients with dyspepsia attending the gastroenterology unit in a tertiary hospital in Mwanza, Tanzania. Afr Health Sci. 2016;16(3):684-9.

8. De Francesco V, Giorgio F, Hassan C, Manes G, Vannella L, Panella C, lerard E, Zullo A. Worldwide H. Pylori antibiotic resistance: a systematic J Gastrointestin Liver Dis. 2010;19(4):409-14.

9. Boyanova L, Mitov I. Geographic map and evolution of primary Helicobacter pylori resistance to antibacterial agents. Expert Rev Anti-Infect Ther. 2010; 8(1):59-70.

10. Megraud F. H pylori antibiotic resistance: prevalence, importance, and advances in testing. Gut. 2004;53(9):1374-84

11. Hunt R, Xiao S, Megraud F, Leon-Barua R, Bazzoli F, van der Merwe S, Coelho LV, Fock M, Fedail S, Cohen H. Helicobacter pylori in developing countries. World Gastroenterol Organ Global Guidelines. 2010:1-15.

12. Fallone CA, Chiba N, van Zanten SV, Fischbach L, Gisbert JP, Hunt RH, Jones NL, Render C, Leontiadis GI, Moayyedi P. The Toronto consensus for the treatment of Helicobacter pylori infection in adults. Gastroenterology. 2016; 151(1):51-69. e14

13. Malfertheiner P, Megraud F, O'morain C, Gisbert J, Kuipers E, Axon A, Bazzoli F, Gasbarrini A, Atherton J, Graham DY. Management of Helicobacter pylori infection — the Maastricht V/Florence consensus report. Gut. 2016;66(1):6-30.

14. Gisbert JP, Molina-Infante J, Amador J, Bermejo F, Bujanda L, Calvet X, Castro-Fernández M, Cuadrado-Lavín A, Elizalde Jl, Gene E. IV Spanish Consensus Conference on Helicobacter pylori infection treatment. Gastroenterología y Hepatología (English Edition). 2016;39(10);697-721.

15. Ghotaslou R, Leylabadlo HE, Asl YM. Prevalence of antibiotic resistance in Helicobacter pylori: a recent literature review. World J Methodol. 2015;5(3):164.

16. Giorgio F, Principi M, De Francesco V, Zullo A, Losurdo G, Di Leo A lerardi E. Primary clarithromycin resistance to Helicobacter pylori: is this the main reason for triple therapy failure. World J Gastrointest Pathophysiol. 2013;4(3):43-6.
17. O'connor A, Lamarque D, Gisbert JP, O'morain C. Treatment of Helicobacter pylori infection 2017. Helicobacter. 2017;22(S1)

18. Henriksen TH, Nysaeter G, Madebo T, Setegn D, Brorson O, Kebede T, Berstad A. Peptic ulcer disease in South Ethiopia is strongly associated with Hebcobacter. Trans R Soc Trop Med Hyg. 1999;93:171-3.

19. Kimang'a AN, Revathi G, Kariuki S, Sayed S, Devani S. Helicobacter pylori: prevalence and antibiotic susceptibility among Kenyans. S Afr Med J. 2000; 100(1):53-7.

20. Abdulrasheed A, Lawal O, Abioye-Kuteyi E, Lamikanra A. Antimicrobial susceptibility of Helicobacter pylori isolates of dyspeptic Nigerian patients. Trop Gastroenterol. 2004;26(2):85-8.

21. Aboderin OA, Abdu A, Odetoyin BW, Okeke IN, Lawa OO, Ndububa DA, Agbakwuru AE, Lamikanra A. Antibiotic resistance of Helicobacter pylori from patients in Ile-lfe, south-west, Nigeria. Afr Health Sci. 2007:7(3).

22. Fathi MS, RF EL-F, Hassan RA, El-Arab ME. Genotypic and phenotypic patterns of antimicrobial susceptibility of Helicobacter pylori strains among Egyptian patients. Egypt J Med Human Genet. 2013;14(3):235-46.

23. Sherif M, Mohran Z, Fathy $H$, Rockabrand DM, Rozmajzl PJ, Frenck RW. Universal high-level primary metronidazole resistance in Helicobacter pylori isolated from children in Egypt. J Clin Microbiol. 2004;42(10):4832-4.

24. Asrat D, Kassa E, Mengistu Y, Nilsson I, Wadström T. Antimicrobial susceptibility pattern of Helicobacter pylori strains isolated from adult dyspeptic patients in Tikur Anbassa university hospital, Addis Ababa, Ethiopia. Ethiop Med J. 2004;42(2):79-85.

25. Secka O, Berg DE, Antonio M, Corrah T, Tapgun M, Walton R, Thomas V, Galano JJ, Sancho J, Adegbola RA. Antimicrobial susceptibility and resistance patterns among Helicobacter pylori strains from the Gambia, West Africa. Antimicrob Agents Chemother. 2013;57(3):1231-7.

26. Ani AE, Malu A, Onah J, Queiroz D, Kirschner G, Rocha G. Antimicrobial susceptibility test of Helicobacter pylori isolated from Jos, Nigeria. Trans R Soc Trop Med Hyg. 1999;93(6):659-61.

27. Mansour KB, Burucoa C, Zribi M, Masmoudi A, Karoui S, Kallel L, Chouaib S, Matri S, Fekih M, Zarrouk S. Primary resistance to clarithromycin, metronidazole and amoxicillin of Helicobacter pylori isolated from Tunisian patients with peptic ulcers and gastritis: a prospective multicentre study. Ann Clin Microbiol Antimicrob. 2010;9(1):22.

28. Seck A, Mbengue M, Gassama-Sow A, Diouf L, Ka MM, Boye CS-B. Antibiotic susceptibility of Helicobacter pylori isolates in Dakar, Senegal. J Infect Dev Countries. 2009;3(02):137-40.

29. Harries A, Stewart M, Deegan K, Mughogho G, Wirima J, Hommel M, Hart C. Helicobacter pyrlori in Malawi, Central Africa. J Infect. 1992;24(3):269-76.

30. Seck A, Burucoa C, Dia D, Mbengue M, Onambele M, Raymond J, Breurec S. Primary antibiotic resistance and associated mechanisms in Helicobacte pylori isolates from Senegalese patients. Ann Clin Microbiol Antimicrob. 2013;12(1):3

31. Tanih NF, Okeleye BI, Naidoo N, Clarke AM, Mkwetshana N, Green E, Ndip LM, Ndip RN. Marked susceptibility of south African Helicobacter pylori strains to ciprofloxacin and amoxicillin: clinical implications. S Afr Med J. 2010;100(1):49-52

32. Ngoyi O, Nina E, Atipo Ibara BI, Moyen R, Apendi A, Clausina P, Ibara JR, Obengui O, Ibara O, Bienvenu R. Molecular detection of Helicobacter pylori and its antimicrobial resistance in Brazzaville, Congo. Helicobacter. 2015; 20(4):316-20.

33. Bouihat N, Burucoa C, Benkirane A, Seddik H, Sentissi S, Al Bouzidi A, Elouennas M, Benouda A. Helicobacter pylori primary antibiotic resistance in 2015 in Morocco: a phenotypic and genotypic prospective and multicenter study. Microb Drug Resist. 2016;

34. Tanih NF, Ndip RN. Molecular detection of antibiotic resistance in south African isolates of Helicobacter pylori. Gastroenterol Res Pract. 2013;2013

35. Khademi F, Poursina F, Hosseini E, Akbari M, Safaei HG. Helicobacter pylori in Iran: a systematic review on the antibiotic resistance. Iran J Basic Med Sci. 2015;18(1):2.

36. Hunt R, Xiao S, Megraud F, Leon-Barua R, Bazzoli F, Van der Merwe S, Vaz Coelho L, Fock M, Fedail S, Cohen H. Helicobacter pylori in developing countries. World gastroenterology organisation global guideline. J Gastrointestin Liver Dis. 2011;20(3):299-304.

37. Glupczynski Y, Megraud F, Lopez-Brea M, Andersen L. European multicentre survey of in vitro antimicrobial resistance in Helicobacter pylori. Eur J Clin Microbiol Infect Dis. 2001;20(11):820-3.

38. Frenck RW, Clemens J. Helicobacter in the developing world. Microbes Infect. 2003;5(8):705-13. 
39. Megraud F, Coenen S, Versporten A, Kist M, Lopez-Brea M, Hirschl AM, Andersen LP, Goossens H, Glupczynski Y, Alarcon T. Helicobacter pylori resistance to antibiotics in Europe and its relationship to antibiotic consumption. Gut. 2013;62(1):34-42

40. Mshana SE, Matee M, Rweyemamu M. Antimicrobial resistance in human and animal pathogens in Zambia, Democratic Republic of Congo, Mozambique and Tanzania: an urgent need of a sustainable surveillance system. Ann Clin Microbiol Antimicrob. 2013;12(1):28.

41. Gebeyehu E, Bantie L, Azage M. Inappropriate use of antibiotics and its associated factors among urban and rural communities of Bahir Dar city administration, Northwest Ethiopia. PLoS One. 2015;10(9):e0138179.

42. Organization $\mathbf{W H}$. Guidelines for the management of sexually transmitted infections. Geneva: WHO; 2001. In: WHO/HIV_AIDS/2001, 01. 2008. Available from http://www.who.int/hiv/pub/sti/en/STIGuidelines2003.pdf. Accessed 20 July 2006

43. Rajper S, Khan E, Ahmad Z, Alam S, Akbar A, Hasan R. Macrolide and fluoroquinolone resistance in Helicobacter pylori isolates: an experience at a tertiary care Centre in Pakistan. J Pak Med Assoc. 2012;62(11):1140-4.

44. Eghbali Z, Mojtahedi A, Ansar MM, AsI SF, Aminian K. Detection of 23SrRNA mutations strongly related to clarithromycin resistance in Helicobacter pylori strains isolated from patients in the north of Iran. Jundishapur J Microbiol. 2016:9(2).

45. Lins AK, Lima RA, Magalhães M. Clarithromycin-resistant Helicobacter pylori in Recife, Brazil, directly identified from gastric biopsies by polymerase chain reaction. Arq Gastroenterol. 2010;47(4):379-82.

46. Sanches BS, Martins GM, Lima K, Cota B, Moretzsohn LD, Ribeiro LT, Breyer HP, Maguilnik I, Maia AB, Rezende-Filho J. Detection of Helicobacter pylori resistance to clarithromycin and fluoroquinolones in Brazil: a national survey. World J Gastroenterol. 2016;22(33):7587.

47. Cambau E, Allerheiligen V, Coulon C, Corbel C, Lascols C, Deforges L, Soussy C-J, Delchier J-C, Megraud F. Evaluation of a new test, genotype HelicoDR, for molecular detection of antibiotic resistance in Helicobacter pylori. J Clin Microbiol. 2009;47(11):3600-7.

48. Deyi VYM, Burette $A$, Bentatou $Z$, Maaroufi $Y$, Bontems $P$, Lepage $P$, Reynders M. Practical use of GenoType ${ }^{\oplus}$ HelicoDR, a molecular test for Helicobacter pylori detection and susceptibility testing. Diagn Microbiol Infect Dis. 2011;70(4):557-60.

49. Eng NF, Ybazeta G, Chapman K, Fraleigh NL, Letto R, Altman E, Diaz-Mitoma F. Antimicrobial susceptibility of Canadian isolates of Helicobacter pylori in northeastern Ontario. Can J Infect Dis Med Microbiol. 2015;26(3):137-44

50. Falush D, Wirth T, Linz B, Pritchard JK, Stephens M, Kidd M, Blaser MJ, Graham DY, Vacher S, Perez-Perez Gl. Traces of human migrations in Helicobacter pylori populations. Science. 2003;299(5612):1582-5.

51. Kim JM, Kim JS, Kim N, Kim Y-J, Kim IY, Chee YJ, Lee C-H, Jung HC. Gene mutations of $23 \mathrm{~S}$ rRNA associated with clarithromycin resistance in Helicobacter pylori strains isolated from Korean patients. J Microbiol Biotechnol. 2008;18(9):1584-9.

52. Agudo S, Pérez-Pérez G, Alarcón T, López-Brea M. High prevalence of clarithromycin-resistant Helicobacter pylori strains and risk factors associated with resistance in Madrid, Spain. J Clin Microbiol. 2010;48(10):3703-7.

53. Hao Q, Li Y, Zhang Z-J, Liu Y, Gao H. New mutation points in 23S rRNA gene associated with Helicobacter pylori resistance to clarithromycin in Northeast China. World J Gastroenterol. 2004;10(7):1075-7.

54. Gressmann H, Linz B, Ghai R, Pleissner K-P, Schlapbach R, Yamaoka Y, Kraft C, Suerbaum S, Meyer TF, Achtman M. Gain and loss of multiple genes during the evolution of Helicobacter pylori. PLoS Genet. 2005;1(4):e43.

55. LMNaRNN T. Characterisation of the genes encoding resistance to metronidazole ( $r d x A$ and frxA) and clarithromycin (the 23S-rRNA genes) in south African isolates of Helicobacter. Ann Trop Med Parasitol. 2011;105(3):251-9.

56. Butlop T, Mungkote N, Chaichanawongsaroj N. Analysis of allelic variants of rdxA associated with metronidazole resistance in Helicobacter pylori: detection of common genotypes in rdxA by multiplex allele-specific polymerase chain reaction. Genet Mol Res. 2016;15(3)

57. Kwon D-H, El-Zaatari FA, Kato M, Osato MS, Reddy R, Yamaoka Y, Graham DY. Analysis of rdxA and involvement of additional genes encoding NAD (P) $\mathrm{H}$ flavin oxidoreductase (FrxA) and ferredoxin-like protein $(\mathrm{FdxB})$ in metronidazole resistance of Helicobacter pylori. Antimicrob Agents Chemother. 2000;44(8):2133-42

58. Marais A, Bilardi C, Cantet F, Mendz GL, Mégraud F. Characterization of the genes rdXA and frxA involved in metronidazole resistance in Helicobacter pylori. Res Microbiol. 2003;154(2):137-44.
59. Toledo H, López-Solís R. Tetracycline resistance in Chilean clinical isolates of Helicobacter pylori. J Antimicrob Chemother. 2010;65(3):470-3.

60. Ribeiro ML, Gerrits MM, Benvengo YH, Berning M, Godoy AP, Kuipers EJ, Mendonça S, van Vliet AH, Pedrazzoli J, Kusters JG. Detection of high-level tetracycline resistance in clinical isolates of Helicobacter pylori using PCRRFLP. FEMS Immunol Med Microbiol. 2004;40(1):57-61.

61. Gerrits MM, Berning M, Van Vliet AH, Kuipers EJ, Kusters JG. Effects of 165 rRNA gene mutations on tetracycline resistance in Helicobacter pylori. Antimicrob Agents Chemother. 2003;47(9):2984-6.

62. Dadashzadeh K, Milani M, Rahmati M, Akbarzadeh A. Real-time PCR detection of 165 rRNA novel mutations associated with Helicobacter pylori tetracycline resistance in Iran. Asian Pac J Cancer Prev. 2014;15:8883-6.

63. Adeniyi BA, TO L, Otegbayo JA, Oluwasola OA, Odaibo GN, Ola SO, Okolo CA, Akere A, Kehinde AO. Cultural characteristics and antibiotic susceptibility pattern of Helicobacter pylori isolated from dyspepsia patients. Gastroenterology Insights. 2012;4(2):21.

64. Angol DC, Ocama P, Ayazika Kirabo T, Okeng A, Najjingo I, Bwanga F. Helicobacter pylori from peptic ulcer patients in Uganda is highly resistant to clarithromycin and fluoroquinolones: results of the GenoType HelicoDR test directly applied on stool. Biomed Res Int. 2017;2017. Article ID 5430723.

65. Ghaith D, Elzahry M, Mostafa G, Mostafa S, Elsherif R, Ramzy I. Mutations affecting domain $\mathrm{V}$ of the $23 \mathrm{~S}$ rRNA gene in Helicobacter pylori from Cairo, Egypt. J Chemother. 2016;28(5):367-70.

66. Djennane-Hadibi F, Bachtarzi M, Layaida K, Ali Arous N, Nakmouche M, Saadi B, Tazir M, Ramdani-Bouguessa N, Burucoa C. High-level primary clarithromycin resistance of Helicobacter pylori in Algiers, Algeria: a prospective multicenter molecular study. Microb Drug Resist. 2016;22(3):223-6.

67. Harrison U, Fowora MA, Seriki AT, Loell E, Mueller S, Ugo-ljeh M, Onyekwere CA, Lesi OA, Otegbayo JA, Akere A. Helicobacter pylori strains from a Nigerian cohort show divergent antibiotic resistance rates and a uniform pathogenicity profile. PLoS One. 2017;12(5):e0176454.

68. Lwai-Lume L, Ogutu E, Amayo E, Kariuki S. Drug susceptibility pattern of Helicobacter pylori in patients with dyspepsia at the Kenyatta National Hospital, Nairobi. East Afr Med J. 2005;82(12):603-8.

69. Ndip RN, Malange Takang AE, Ojongokpoko JE, Luma HN, Malongue A, Akoachere JF, Ndip LM, MacMillan M, Weaver LT. Helicobacter pylori isolates recovered from gastric biopsies of patients with gastro-duodenal pathologies in Cameroon: current status of antibiogram. Trop Med Int Health. 2008;13(6):848-54.

70. Smith SI, Oyedeji KS, Arigbabu AO, Atimomo C, Coker AO. High amoxycillin resistance in Helicobacter pylori isolated from gastritis and peptic ulcer patients in western Nigeria. J Gastroenterol. 2001;36(1):67-8.

71. National Committee for Clinical Laboratory Standards. Approved Standard M7-A5: Methods/or Dilution Antimicrobial Susceptibility Tests/or Bacteria That Grow Aerobically (National Committee for Clinical laboratory Standards Wayne, PA). 2000

72. Thomsbbery CS, L. D. In: Manual of Clinical Microbiology. 4th edition. edn. Edited by Lennete BH, Balows, A., Hausler, W. J. \& Shadomy, J. H. Washington, D.C: ASM Publications; 1985: pp. 1021-1022.

73. Hachem CY, Clarridge JE, Reddy R, Flamm R, Evans DG, Tanaka SK, Graham DY. Antimicrobial susceptibility testing of Helicobacter pylori comparison of E-test, broth microdilution, and disk diffusion for ampicillin, clarithromycin, and metronidazole. Diagn Microbiol Infect Dis. 1996;24(1):37-41.

74. Cederbrant $G$, Kahlmeter $G$, Ljungh Â. The E test for antimicrobial susceptibility testing of Helicobacter pylon. J Antimicrob Chemother. 1993; 31(1):65-71

75. Institute: CaLS. Performance standards for antimicrobial susceptibility testing; twentieth informational supplement, CLSI document. Wayne, PA: Clinical and Laboratory Standards Institute; 2012. M100-S22

76. Chaabouni HB, H Masmoudi, A Cheikh, I Fendri, C Ammar, A Ben: Evaluation in vitro de la resistance primaire de helicobacter pylori aux antibiotiques chez les malades souffrant d'ulcere duodenal en tunisie. Gastroenterologie clinique et biologique 2004, 28:A135-A135.

77. Mégraud F, Lehn N, Lind T, Bayerdörffer E, O'Morain C, Spiller R, Unge P, van Zanten SV, Wrangstadh M, Burman CF. Antimicrobial susceptibility testing ofHelicobacter pylori in a large multicenter trial: the MACH 2 study. Antimicrob Agents Chemother. 1999;43(11):2747-52. 